\title{
LINEAR REGRESSION ANALYSIS ON THE FACTORS ASSOCIATED WITH UNSAFE SEXUAL BEHAVIOR AMONG MEN WHO HAVE SEX WITH MEN IN SURAKARTA
}

\author{
Siti Nurhalimah'), Hanung Prasetya'2), Bhisma Murti') \\ ${ }^{1)}$ Masters Program in Public Health, Universitas Sebelas Maret \\ ${ }^{2}$ School of Health Polytechnics Surakarta
}

\begin{abstract}
Background: Sexual behavior among men who have sex with men (MSM) was associated with the increasing of sexually transmitted disease (STD). In Indonesia, the number of STD cases among MSM in 2017 was 4,144. The purpose of this study was to examine factors associated with unsafe sexual behavior among MSM in Surakarta, using Theory of Planned Behavior (TPB).

Subjects and Method: A cross sectional study was conducted in Surakarta, Central Java, in November 2018. A sample of $188 \mathrm{MSM}$ was selected by fixed disease sampling, consisting of $47 \mathrm{MSM}$ with STD positive and $141 \mathrm{MSM}$ without STD. The dependent variable was unsafe sexual behavior. The independent variables were knowledge, intention, attitude, subjective norm, and perceived behavior control. Data on STD status were obtained from medical record. The other data were collected by questionnaire. The data were analyzed by a multiple linear regression.

Results: Unsafe sexual behavior directly increased with strong intention $(b=0.19 ; 95 \% \mathrm{CI}=$ 0.06 to $0.32 ; \mathrm{p}=0.003)$. Unsafe sexual behavior directly decreased with better knowledge $(\mathrm{b}=-0.30 ; 95 \% \mathrm{CI}=-0.38$ to $-0.11 ; \mathrm{p}<0.001)$. It was indirectly associated with attitude, subjective norm, and perceived behavior control.

Conclusion: Unsafe sexual behavior directly increases with strong intention, but decreases with better knowledge. It is indirectly associated with attitude, subjective norm, and perceived behavior control.
\end{abstract}

Keywords: unsafe sexual behavior, Theory of Planned Behavior

Correspondence:

Siti Nurhalimah. Masters Program in Public Health, Universitas Sebelas Maret. Jl. Ir. Sutami 36 A, Surakarta 57126, Central Java, Indonesia. Email: halimah1006.mdf@gmail.com. Mobile: 082233890866

The 5th International Conference on Public Health Best Western Premier Hotel, Solo, Indonesia, February 13-14, 2019 | 168 https://doi.org/10.26911/theicph.2019.02.13 